\begin{tabular}{|c|c|c|}
\hline 中村東一郎 & 高橋 & 恒男 \\
\hline 冨樫＼cjkstart整 & 石川 & 誠* \\
\hline
\end{tabular}

\begin{abstract}
要 旨：肝スライス培養法で, paraquat $\left(\mathrm{PQ}^{2+}\right)$ 活性酸素肝障害に対する小柴胡湯の障害抑制

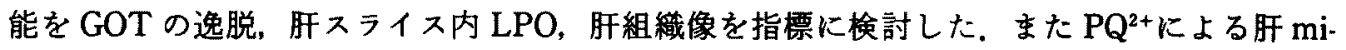
crosome 脂質過酸化反応への小柴胡湯の影響も検討した。 その結果，1）小柴胡湯は $\mathrm{PQ}^{2+}$ 肝障 害を抑制し，抑制の程度は小柴胡湯 $1000 \mu \mathrm{g} / \mathrm{m} l$ 投与が最も強く，次に $100 \mu \mathrm{g} / \mathrm{m} l, 10 \mu \mathrm{g} / \mathrm{m} l$, $1 \mu \mathrm{g} / \mathrm{m} l$ の順であった。 小柴胡湯の添加時期を $\mathrm{PQ}^{2+}$ 添加前(前投与), 同時期(同時投与), $\mathrm{PQ}^{2+}$ 添加後（後投与）に分けて肝障害の抑制を娭討すると，いずれる肝障害を抑制したか，前投与 が最もよく障害を抑制し，同時投与がこれに次いた．2）小柴胡湯は $\mathrm{PQ}^{2+}$ ，肝 microsome， NADPH generating systemによる肝 microsome 脂質過酸化反応を抑制した。柴胡湯構成 生薬の中では荅, 甘草, 柴胡が肝 microsome 脂質過酸化反応を抑制した。 以上のことから小柴 胡湯は $\mathrm{PQ}^{2+}$ による活性酸素肝障害を抑制する可能性が有ると思われた。
\end{abstract}

索引用語：バラコート 肝障害 活性酸素 小柴胡湯 肝スライス培養

\section{楮 言}

小柴胡湯は柴胡, 半夏, 黄芦, 人参, 生姜, 大東, 甘草からなる漢方方剂である。歴史的には張仲景に よって西暦 2 世粑頃に著わされたと伝えられる傷寒論 に初めてその記載がみられる”. 以来, 本刘は伝染性疾 患から消化器㲛患, 呼吸器疾患, またいわゆる不定愁 訴から精神神経疾患に至るまで多くの疾病に処方され てきた。特に近年は肝垁患で処方されることが多い2． 小柴胡湯の肝機能障害軽減作用は, 抗炎症作用, 抗只 イルス作用などによるるのとされているが3)，末たそ の作用機序は不明である。

除草剤として広く用いられているパラコート(Paraquat 以下 $\mathrm{PQ}^{2+}$, methyl viologen, $1,1^{\prime}$-dimethyl-4, 4'-bipyridinium ion）は動物において肺や肝荿など多 䁍器に障害を起こし, 死しに至らせることが知られて いる.ヒトでる本珴を自殺目的で，あるいは誤って服 用した場合，肝障害や呼吸不全を起こし，死亡するこ

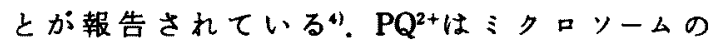
NADPH-cytochrome reductase に還元されて paraquat free radical になる. paraquat free radical は酸 素と反応して $\mathrm{O}_{2}{ }^{-}$(superoxide)を発生する， $\mathrm{O}_{2}$-はさ

- 山形大学第 2 内科

〈受付日1990年 4 月26日 $>$

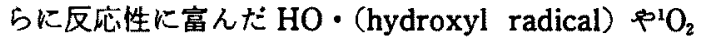
(singlet $\mathrm{O}_{2}$ )を生成し, 瞙脂質を過酸化することから, $\mathrm{PQ}^{2+}$ の藏器障害性は活性酸素に上る脂質過酸化に起 因するとされている4.5)。我々は肝スライスを用いた in vitroの実験で， $\mathrm{PQ}^{2+か ゙ ~} \mathrm{O}_{2}$ ーにより肝細胞を障害する ことを確認している6,7).

そこで小柴胡湯の肝障害抑制機序の解明のために肝 スライス培姜法を用いて, $\mathrm{PQ}^{2+}$ 肝障害に対する小柴胡 湯の影部を㭘討した。 その結果, 小柴胡湯は $\mathrm{PQ}^{2+}$ 肝障 害を抑制することを明らかにした。さらに microsomal lipid peroxidation を用いた実験から小柴胡 湯には活性酸素消去能があることを示しえた。した がって, 小柴胡湯の $\mathrm{PQ}^{2+}$ 解障害抑制は $\mathrm{O}_{2}$-消去に関連 する可能性があるすのと考えられたので報告する。

\section{材料と方法}

1. ラット肝スライスでの $\mathbf{P Q}^{2+}$ の肝障害に封する 小柴胡湯の抑制効果

肝スライス作成は富樫らの方法ので行なった。すな わち体重200g の Wistar 系雄性ラットを用い，12時間 絶食後，ペントバルビタール $(50 \mathrm{mg} / \mathrm{m} l) 0.2 \mathrm{~m} l$ の腹 腔内投与で麻酔し開腹した。下大静脈を切断し，門脈 から Krebs-Ringer 液にて肝を灌流し，脱血した、脱血 した訮から注は $5 \times 5 \times 30 \mathrm{~mm}$ の直方体の検体を切り出 した，なお，切り出す部位は常に一定とした，切り出 
した肝を Krebs-Ringer 液中に浸し，95\% $\mathrm{O}_{2}+5 \%$ $\mathrm{CO}_{2}$ を通気しながら Kaneda らの rotary slicer い, 1 辺 $5 \mathrm{~mm}$, 厚さ $0.3 \mathrm{~mm}$ の均一な肝スライスを連続 して作成した. $95 \% \mathrm{O}_{2}+5 \% \mathrm{CO}_{2}$ の条件下でスライス 1 枚を $1 \mathrm{~m} l$ の培養液中で培姜した. Rotary slicer を用 いることにより，均一で挫隇の少ないスライスを毎分 約 4 枚作成しえた，培盖液は Eagle's MEM “Nissui” （日水製薬，東京） $4.7 \mathrm{~g}$, L-Glutamine（日水製薬） 15 $\mathrm{mg}$, 重炭酸ナトリウム $1 \mathrm{~g}$ とブドウ榶5g を蒸留水500 $\mathrm{m} l$ に溶解したもの(以下 MEM)"である. 肝スライス を90分間 preincubation し，その啳 MEM を変え 2 時 間培養 (1st incubation), 再び MEM を変え 6 時間培 盖 (2nd incubation) した.

\section{A. 小柴胡湯の投与量別検討}

Preincubationでの小柴胡湯投与の有無，投与量，1 st incubation での $\mathrm{PQ}^{2+}$ 投与の有無により以下の 6 群 に分けた (Fig. 1).

1) 対照群: Preincubation か 52nd incubation でMEMのみで培着したもの.

2) $\mathrm{PQ}^{2+}$ 群 : 1st incubation で $\mathrm{PQ}^{2+}$ を $\mathrm{MEM}$ 中で5 $\mathrm{mM} / \mathrm{m} l$ になるよらに投与し, preincubation, 2nd incubationは MEMのみで培養したもの.

以下の3）－6） $\mathrm{PQ}^{2+}+$ 小柴胡湯群は preincubation でMEMに小柴胡湯を容解して投与し，後は $\mathrm{PQ}^{2+}$ 群 と同様に培盖したものである。小柴胡湯投与量を $\mathrm{MEM}$ 中の小柴胡湯濃度により3） $\mathrm{PQ}^{2+}+$ 小柴胡湯 1 $\mu \mathrm{g} / \mathrm{m} l$ 群, 4) $\mathrm{PQ}^{2+}$ 十小柴胡湯 $10 \mu \mathrm{g} / \mathrm{m} l$ 群，5) $\mathrm{PQ}^{2+}$ 小柴胡湯 $100 \mu \mathrm{g} / \mathrm{m} l$ 群，6） $\mathrm{PQ}^{2+}+$ 小柴胡湯 $1000 \mu \mathrm{g} /$ $\mathrm{m} l$ 群の 4 群とした。

各群の肝障害の程度は1st incubation 開始から 2 , $4 ， 6 ， 8$ 時間後の培羡上清中の GOT, 肝スライス中 過酸化脂質（以下 LPO）を測定することで，また，6 時間， 8 時間後の組織学的変化をみることにより検討 した，組織学的変化は，肝スライスの一切片での全肝 細胞に対する壊死肝細胞の割合により,一（10\%末 満), \pm ( $10 \%$ 以上 $20 \%$ 末満),+ (20\%以上 $30 \%$ 未満), \# (30\%以上 $40 \%$ 末満)， + (40\%以上)の 5 段階に分 けた。

B. 小柴胡湯の投与時期別検討

小柴胡湯の投与量を $100 \mu \mathrm{g} / \mathrm{m} l$ とし，小柴胡湯の投 与時期を变え，愉討した（Fig. 2).

$\mathrm{A}$ と同様に1）対照群，2） $\mathrm{PQ}^{2+}$ 群とした。
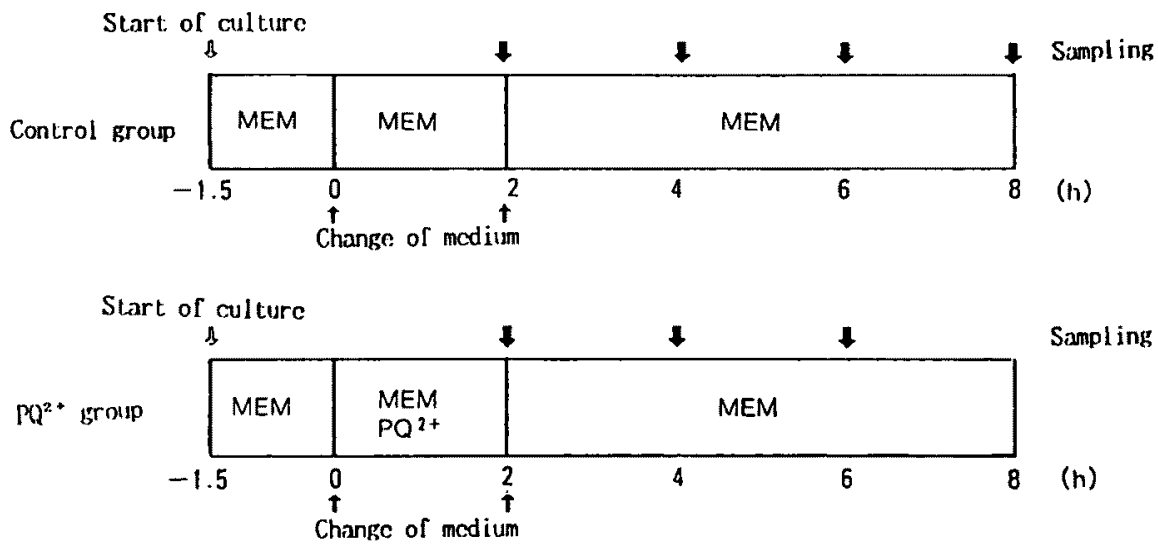

Sampl ing

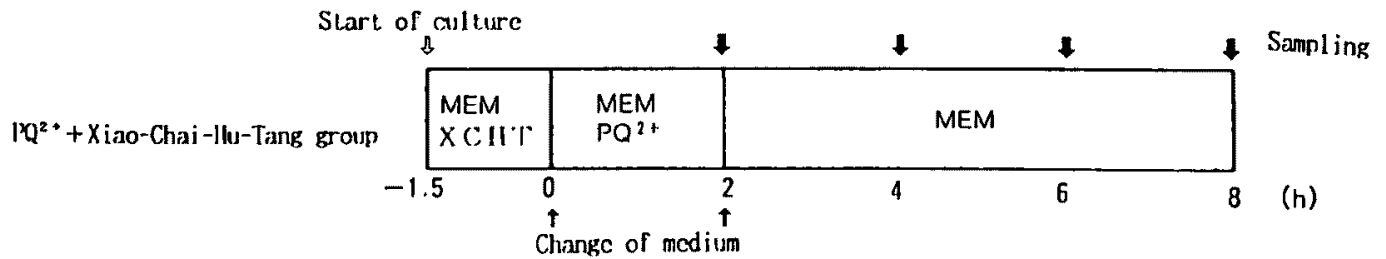

Fig. 1 Timetable for liver slice cultures.

MEM : Eagle's MEM, $\mathrm{PQ}^{2+}:$ Paraquat $(5 \mathrm{mM} / \mathrm{m} l)$, XCHT : Xiao-Chai-Hu-Tang $(1 \mu \mathrm{g} / \mathrm{ml}, 10 \mu \mathrm{g} / \mathrm{m} l, 100 \mu \mathrm{g} / \mathrm{m} l, 1000 \mu \mathrm{g} / \mathrm{m} l), \mathrm{h}:$ hours after start of first incubation 

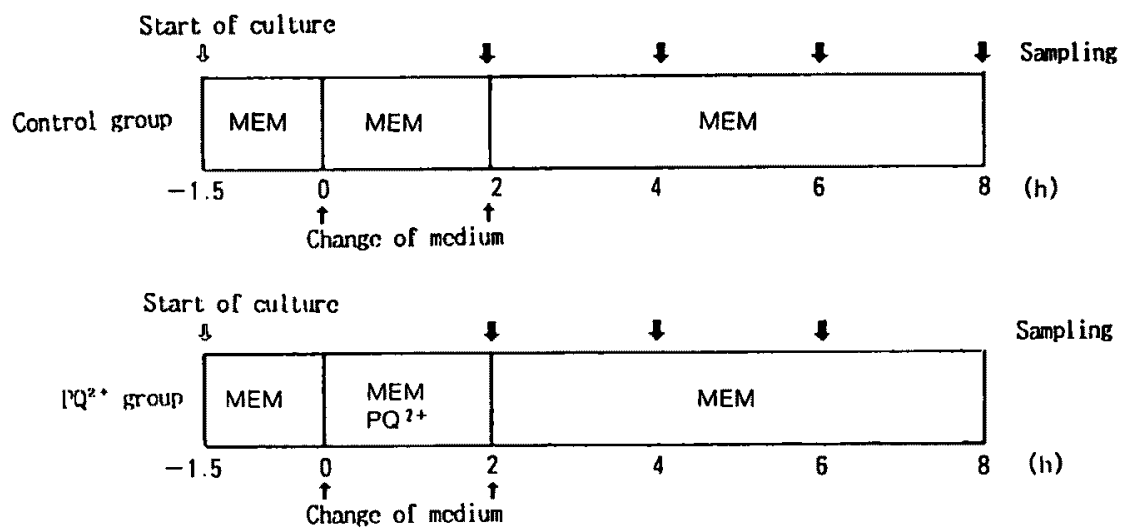

Sampling

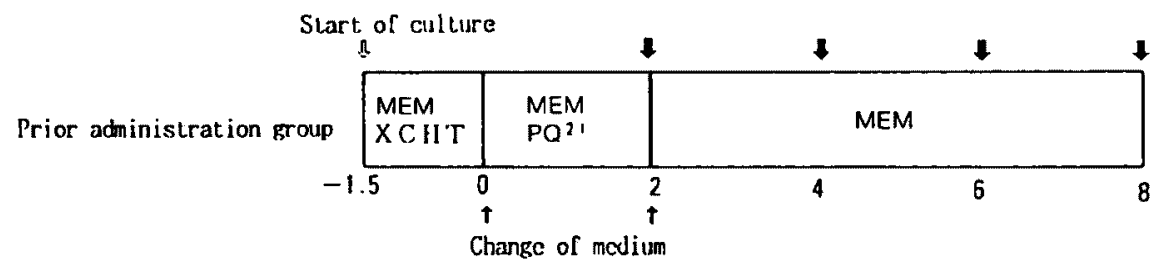

Sampling
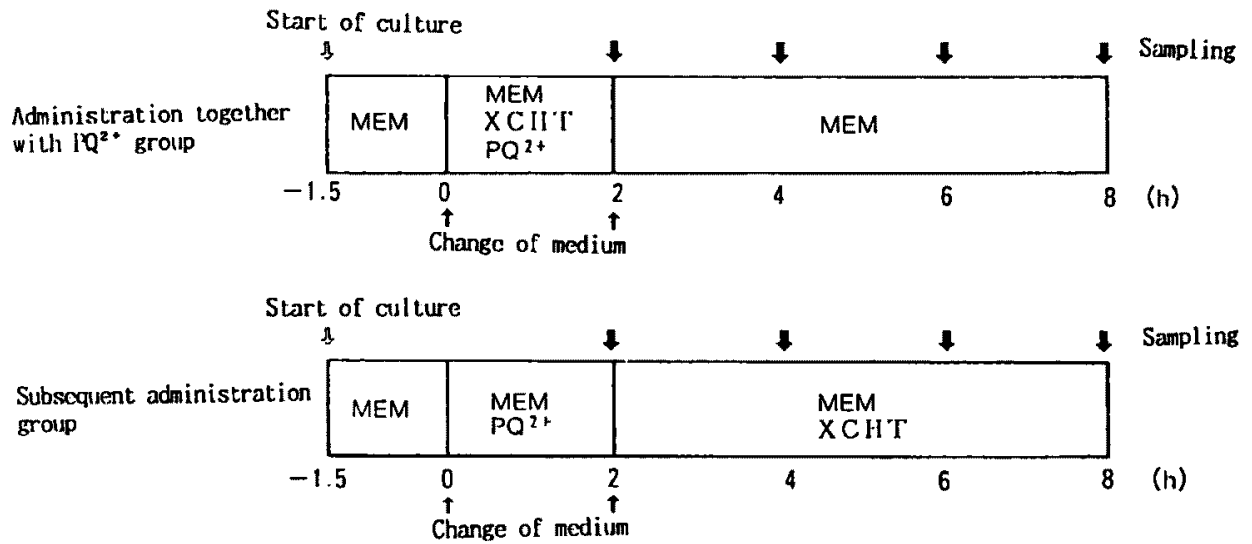

Fig. 2 Timetable for liver slice cultures. Timing of Xiao-Chai-Hu-Tang administration.

MEM : Eagle's MEM, $\mathrm{PQ}^{2+}:$ Paraquat $(5 \mathrm{mM} / \mathrm{m} l)$, XCHT : Xiao-Chai-Hu-

Tang $(100 \mu \mathrm{g} / \mathrm{m} l), \mathrm{h}:$ hours after start of first incubation

3）前投与群：preincubationで MEM に小柴胡湯 を $100 \mu \mathrm{g} / \mathrm{m} l$ 投与し, 後は $\mathrm{PQ}^{2+}$ 群と同様に培盖した.

4）同時投与群：preincubation は MEM のみで，1 st incubation で MEM K小柴胡湯 $100 \mu \mathrm{g} / \mathrm{m} l$ と $\mathrm{PQ}^{2+}$ を同時に投与し，2nd incubation は MEMのみで培堑 した.

5）小柴胡湯後投与群：1st incubationまでは $\mathrm{PQ}^{2+}$ 群と同様に, 2nd incubation で MEMに小柴胡湯を $100 \mu \mathrm{g} / \mathrm{m} l$ 投与した。
A と同様に, 肝障害の程度を培養上清中の GOT, 肝 スライス中LPOを測定することにより検討した。

Paraquat はングマ社 (St. Louis) の98\% methyl viologenを, 小柴胡湯はッムラ小柴胡湯エキス原末 (ッムラ、東京)を用いた。

GOT測定はCiba-Corning 社製キットを用いて UV 法で行ないは，LPO 湘定は肝スライスをホモジェ ネートとし，さらにホモジェネートの上清を検体とし てデタミナーLPO (協和メデックス, 東京)を用いて 
八木別法で行なっだ!. 肝ホモジェネートは肝スライ ス 1 枚に $0.5 \%$ triton $\mathrm{X} 1 \mathrm{~m} l$ を加光，テフロンホ乇 シェナイザーで作成した。をてして $4{ }^{\circ} \mathrm{C} ， 700 \times \mathrm{g} 10$ 分間 遠心し，その上清を LPO 湘定用の検体とした。

GOT はIU/L, LPO は nmol/mg 蛋白で表わした。 な技蛋白量はLPO測定用の挨体をMicro TP-Test (和光純薬，大阪 $)^{12)}$ で測定した，GOT，LPO，蛋白の 測定はいずれも Gilford Impact 400 (Ciba Corning Diagnostics Corp. USA) で行なった.

\section{Microsomal lipid peroxidation での検討}

Microsomal lipid peroxidationは,以下のごとく Trush $^{131}$ らの方法で行なった.

\section{A. 実験材料の調整}

1) 肝ミクロンーム

体重200gの Wistar 系雄性ラットを,フェノハルビ タール $1 \mathrm{mg} / \mathrm{m} l$ 含有した水で 1 週間飼育し， 1 ，と同 様な方法で開腹した，下大静脈を切断し，門脈から 150

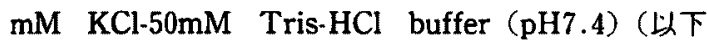
$\mathrm{KCl}$-Tris-HCl buffer) で，所を篧流し摘出した。この 肝をハサミで細切し，肝1gに KCl-Tris-HCl buffer 4 $\mathrm{m} l$ の割合で加文、テフロンホモシェナイザーでホモ シェネートを作成した．ホモシェネートを $9 \times 10^{3} \times \mathrm{g}$ で20分遠心した，上清を $10^{5} \times \mathrm{g} て ゙ 60$ 分超遠心し，沈殿 したミクロンーム分画を取り出した。これを $3.5 \mathrm{mg}$ 蛋 白 $/ \mathrm{ml}$ に調整し，肝ミクロンームとした。

2) NADPH generating system

$\boldsymbol{\beta}$-nicotinamide adenine dinucleotide phosphate (NADP) 1.9mM, glucose-6-phosphate(G6P) $20 \mathrm{mM}$, glucose-6-phosphate dehydrogenase (G6P-D) 1.1IU/ $\mathrm{m} l, \mathrm{MgCl}_{2} 9 \mathrm{mM}$ を KCl-Tris- $\mathrm{HCl}$ buffer に溶解した るのを NADPH generating system とした. NADP, G6P, G6P-D はングマ社 (St. Louis)の試薬を用いた.

3) $\mathrm{PQ}^{2+}$ 溶液

終浱度 $0.1 \mathrm{mM} / \mathrm{m} l$ Kなるよう K KCl-Tris- $\mathrm{HCl}$ buffer K $\mathrm{PQ}^{2+}$ 溶解し，これを $\mathrm{PQ}^{2+}$ 容液とした。

\section{4) 小柴胡湯}

終濃度が $1 \mu \mathrm{g} / \mathrm{m} l, 10 \mu \mathrm{g} / \mathrm{m} l, 100 \mu \mathrm{g} / \mathrm{ml}, 1000 \mu \mathrm{g} /$ $\mathrm{m} l$ になるように小柴胡湯を KCl-Tris-HCl buffer に 溶解し，これらを小柴胡湯溶液とした。

\section{5）小柴胡湯構成生菜}

小柴胡湯の 1 日投与分には柴胡 $7.0 \mathrm{~g}$, 半夏 $5.0 \mathrm{~g}$, 黄 希 $3.0 \mathrm{~g}$ ，人参 $3.0 \mathrm{~g}$ ，生姜 $1.0 \mathrm{~g}$ ，大東 $3.0 \mathrm{~g}$ ，甘草 $2.0 \mathrm{~g}$ が 含まれている。これらの7種の生沓の小柴胡湯 1 日相 当量を混合し, 水煎抽出し, 乾燥させたものが小柴胡
湯エキスである。この小柴胡湯 1 日投与分から得られ るエキスは乾燥重量4.5gになる，7種の生薬を雨谷 ら"1の方法に準し，各個に水煎抽出し，凍結乾燥土キス とした。これら7種の生萩エキスから小柴胡湯エキス $1000 \mu \mathrm{g}$ に相当する量を個々に計量した.これらのエキ スを各々 KCl-Tris-HCl buffer に溶解し，各生菜溶液 とした。

使用した小柴胡湯構成生菜は日本菜局方適合品で柴 胡 (中国産)，半夏 (中国産)，黄芩(中国産)，人参(日 本産)，生姜 (中国産)，大患 (中国産)，甘草 (中国産) ともウチダ和漢薬 (東京) の市販品を用いた。

B. 実験群の設定

1) 小柴胡湯での検討

対照群, $\mathrm{PQ}^{2+}$ 群の 2 群と小柴胡湯の 4 種の湦度によ る $\mathrm{PQ}^{2+}+$ 小柴胡湯群の計 6 群に分けた。

a) 対照群：NADPH generating system $1 \mathrm{~m} l$, 肝 ミクロンー $\triangle 0.15 \mathrm{~m} l \mathrm{k}, \mathrm{KCl}$. Tris. $\mathrm{HCl}$ buffer $0.6 \mathrm{ml}$ を混合した。

b) $\mathrm{PQ}^{2+}$ 群：対照群に $\mathrm{PQ}^{2+}$ 容液 $0.5 \mathrm{~m} l$ を加えたも のであるが KCl-Tris-HCl buffer は0. $\operatorname{lm} l$ とした。

以下のc）－f） $\mathrm{PQ}^{2+}$ 十小柴胡湯群は対照群から $\mathrm{KCl}$-Tris- $\mathrm{HCl}$ buffer t除き, $\mathrm{PQ}^{2+}$ 溶液 $0.5 \mathrm{ml}$, 小柴 胡湯容液 $0.1 \mathrm{~m} l$ を混合したものであり，小柴胡湯終漶 度より，c） $\mathrm{PQ}^{2+}$ 十小柴胡湯 $1 \mu \mathrm{g} / \mathrm{m} l$ 群, d) $\mathrm{PQ}^{2+}+$ 小 柴胡湯 $10 \mu \mathrm{g} / \mathrm{m} l$ 群, e) $\mathrm{PQ}^{2+}+$ 小柴胡湯 $100 \mu \mathrm{g} / \mathrm{m} l$ 群, f) $\mathrm{PQ}^{2+}+$ 小柴胡湯 $1000 \mu \mathrm{g} / \mathrm{m} l$ 群とした。

\section{2. 小柴胡湯構成生薬での検討}

小柴胡湯の microsomal lipid peroxidation と同様 に，a）対照群， b) $\mathrm{PQ}^{2+}$ 群とした。

以下の c) - i) $\mathrm{PQ}^{2+}$ 十小柴胡湯構成生䓙群は対照群 から KCl-Tris-HCl buffer を除き， $\mathrm{PQ}^{2+}$ 容液 $0.5 \mathrm{~m} l$, 小柴胡湯構成生蓧客液 $0.1 \mathrm{~m} l$ を混合したものであり， 小柴胡湯構成生菜に上り，c） $\mathrm{PQ}^{2+}+$ 黄芩群, d) $\mathrm{PQ}^{2+}+$ 甘草群, e) $\mathrm{PQ}^{2+}$ 柴胡群, f) $\mathrm{PQ}^{2+}+$ 生姜群, g) $\mathrm{PQ}^{2+}+$ 半夏群, h) $\mathrm{PQ}^{2+}+$ 人参群, i) $\mathrm{PQ}^{2+}+$ 大東 群とした。

\section{C. 実験法}

まず，遮光スピッッに NADPH generating system $1 \mathrm{~m} l$ を入れ，次に小柴胡湯または小柴胡湯粠成生薬溶 痹 (対照群, $\mathrm{PQ}^{2+}$ 群は KCl-Tris- $\mathrm{HCl}$ buffer) $0.1 \mathrm{~m} l$ を入れ， $\mathrm{PQ}^{2+}$ 溶液（対照群は KCl-Tris-HCl buffer） $0.5 \mathrm{~m} l$ を入れた，最後に肝ミクロソーム $0.15 \mathrm{~m} l$ を入 れ反応を開始した，反応は $37^{\circ} \mathrm{C} ， \mathrm{O}_{2} 100 \%$ の条件で振 湯しつつ行なった. Microsomal lipid peroxidationの 
程度は30分，60分，90分，120分と経時的に過酸化脂質 産生量を測定して評価した。なお LPOは $\mathrm{nmol} / \mathrm{m} l$ で 表わした。

測定值は mean \pm S.E.で表わし， $\mathrm{PQ}^{2+}$ 群と他の群と の有意差検定は Student's t-test で行ない，危険率 $5 \%$ 未満を有意とした。

\section{結果}

1. $\mathbf{P Q}^{2+}$ の肝障害性に対する小柴胡湯の肝障害抑制 効果

\section{A. 小柴胡湯の投与量別肝障害抑制奻果}

培養上清中 GOT は (Table 1) 対照群, $\mathrm{PQ}^{2+}$ 群で， それぞれ 2 時間 $36 \pm 6 \mathrm{IU} / \mathrm{L}, 64 \pm 12 \mathrm{IU} / \mathrm{L} ， 4$ 時間 $48 \pm$ $8 \mathrm{IU} / \mathrm{L}, 57 \pm 13 \mathrm{IU} / \mathrm{L}, 6$ 時間75 $\pm 7 \mathrm{IU} / \mathrm{L}, 247 \pm 34$ $\mathrm{IU} / \mathrm{L} ， 8$ 時間 $162 \pm 20 \mathrm{IU} / \mathrm{L} ， 499 \pm 56 \mathrm{IU} / \mathrm{L}$ と対照群 に対して $\mathrm{PQ}^{2+}$ 群では 6 時間， 8 時間で有意 $(\mathrm{p}<0.01)$ に高値たった。 $\mathrm{PQ}^{2+}+$ 小柴胡湯 $1 \mu \mathrm{g}$ 群，10 $\mu \mathrm{g}$ 群，100 $\mu \mathrm{g}$ 群， $1000 \mu \mathrm{g}$ 群はそれぞれ 6 時間 $103 \pm 29 \mathrm{IU} / \mathrm{L}$, $79 \pm 21 \mathrm{IU} / \mathrm{L}, 63 \pm 15 \mathrm{IU} / \mathrm{L}, 62 \pm 13 \mathrm{IU} / \mathrm{L}, 8$ 時間 $218 \pm$ $63 \mathrm{IU} / \mathrm{L}, 155 \pm 97 \mathrm{IU} / \mathrm{L}, 133 \pm 34 \mathrm{IU} / \mathrm{L}, 91 \pm 16 \mathrm{IU} /$ $\mathrm{L}$ と， $\mathrm{PQ}^{2+}$ 群に比べ有意に低かった。

肝組織中 LPOは (Table 1) 対照群，PQ2+群でそれ ぞれ 2 時間 $5.65 \pm 0.26 \mathrm{nmol} / \mathrm{mg}$ 蛋白, $5.78 \pm 0.22$ $\mathrm{nmol} / \mathrm{mg}$ 蛋白, 4 時間 $5.72 \pm 0.23 \mathrm{nmol} / \mathrm{mg}$ 蛋白, $6.58 \pm 0.41 \mathrm{nmol} / \mathrm{mg}$ 蛋白, 6 時間 $5.75 \pm 0.26 \mathrm{nmol} /$ $\mathrm{mg}$ 蛋白, $7.63 \pm 0.28 \mathrm{nmol} / \mathrm{mg}$ 蛋白, 8 時間 $6.60 \pm$ $0.20 \mathrm{nmol} / \mathrm{mg}$ 蛋白, $12.93 \pm 0.98 \mathrm{nmol} / \mathrm{mg}$ 蛋白と対照 群に対して $\mathrm{PQ}^{2+}$ 群では 6 時間， 8 時間で有意 $(\mathrm{p}<$ 0.01)に高かった。

$\mathrm{PQ}^{2+}+$ 小柴胡湯 $1 \mu \mathrm{g}$ 群, $10 \mu \mathrm{g}$ 群, $100 \mu \mathrm{g}$ 群, $1000 \mu \mathrm{g}$ 群はそれぞれ 6 時間で7.04 $0.56 \mathrm{nmol} / \mathrm{mg}$ 蛋白,
$6.27 \pm 0.69 \mathrm{nmol} / \mathrm{mg}$ 蛋白, $6.41 \pm 0.49 \mathrm{nmol} / \mathrm{mg}$ 蛋白, $6.03 \pm 0.19 \mathrm{nmol} / \mathrm{mg}$ 蛋白, 8 時間では7.68 0.76 $\mathrm{nmol} / \mathrm{mg}$ 蛋白, $7.00 \pm 0.68 \mathrm{nmol} / \mathrm{mg}$ 蛋白, $7.23 \pm 0.57$ $\mathrm{nmol} / \mathrm{mg}$ 蛋白 $6.36 \pm 0.40 \mathrm{nmol} / \mathrm{mg}$ 蛋白であり，6時 間では小柴胡湯 $1000 \mu \mathrm{g}$ 群で $\mathrm{PQ}^{2+}$ 群に比べ有意に低 < 8 時間では $\mathrm{PQ}^{2+}$ 十小柴胡湯各群とも有意に低かっ た。

組織学的には対照群で壊死細胞の割合が 6 時間， 8 時間 (Fig. 3A) ともに士なのに対し $\mathrm{PQ}^{2+}$ 群では 6 時 間で十，8時間(Fig. 3B)でサだった， $\mathrm{PQ}^{2+}+$ 小柴胡 湯群では 6 時間でー，8 時間（Fig，3C）で士と $\mathrm{PQ}^{2+}$ 群に比べ壊死細胞は少なかった（Table 2).

B. 小柴胡湯の投与時期別検討

$\mathrm{PQ}^{2+}$ 群，前投与群，同時投与群，後投与群の培養上 清中 GOT は（Table 3）それぞれ，6時間で $247 \pm 34$ $\mathrm{IU} / \mathrm{L}, 63 \pm 15 \mathrm{IU} / \mathrm{L}, 56 \pm 6 \mathrm{IU} / \mathrm{L}, 113 \pm 31 \mathrm{IU} / \mathrm{L}$, 8 時間では499 $\pm 56 \mathrm{IU} / \mathrm{L}, 133 \pm 34 \mathrm{IU} / \mathrm{L}, 135 \pm 34 \mathrm{IU} /$ $\mathrm{L}, 214 \pm 46 \mathrm{IU} / \mathrm{L}$ であり， $\mathrm{PQ}^{2+}$ 群に比へ，前投与群， 同時投与群 $(p<0.001)$ ，後投与群 $(p<0.05)$ ともに 有意に低かった。

肝スライス中 LPO は（Table 3）6 時間では 3 者と す $\mathrm{PQ}^{2+}$ 群に比輘して有意差は無かった，8時間では $\mathrm{PQ}^{2+}$ 群 $12.93 \pm 0.98 \mathrm{nmol} / \mathrm{mg}$ 蛋白, 前投与群 $7.23 \pm$ $0.57 \mathrm{nmol} / \mathrm{mg}$ 蛋白，同時投与群 $7.72 \pm 0.30 \mathrm{nmol} / \mathrm{mg}$ 蛋白, 後投与群 $8.77 \pm 0.65 \mathrm{nmol} / \mathrm{mg}$ 蛋白と,前投与群, 同時投与群, 後投与群の順に低值を示したが $\mathrm{PQ}^{2+}$ 群 に比べ前投与群，同時投与群，後投与群とも有意（前 投与群 $\mathrm{p}<0.01$, 同時投与群, 後投与群 $\mathrm{p}<0.05)$ に低 かった。

\section{Microsomal lipid peroxidation での検討}

Table 1 Effect of Xiao-Chai-Hu-Tang on paraquat ( $\mathrm{PQ}^{2+}$ )-induced liver injury.

\begin{tabular}{|c|c|c|c|c|c|c|c|c|c|}
\hline & \multirow{2}{*}{$\mathbf{n}$} & \multicolumn{4}{|c|}{ GOT $(I U / L)$} & \multicolumn{4}{|c|}{ Lipid peroxide (nmol/mg protein) } \\
\hline & & $2 \mathrm{hr}$ & $4 \mathrm{hr}$ & $6 \mathrm{hr}$ & $8 \mathrm{hr}$ & $2 \mathrm{hr}$ & $4 \mathrm{hr}$ & $6 \mathrm{hr}$ & $8 \mathrm{hr}$ \\
\hline Contr & 8 & $36 \pm 6$ & $48 \pm 8$ & $75 \pm 7$ & $162 \pm 20$ & $5.65 \pm 0.26$ & $5.72 \pm 0.23$ & $5.75 \pm 0.26$ & $6.60 \pm 0.20$ \\
\hline$P Q^{2+}$ group & 8 & $64 \pm 12$ & $57 \pm 13$ & $247 \pm 34^{\circ}$ & $499 \pm 56^{\circ}$ & $5.78 \pm 0.22$ & $6.58 \pm 0.41$ & $7.63 \pm 0.28^{\star}$ & $12.93 \pm 0.98^{\circ}$ \\
\hline $\mathrm{PQ}^{2+}+\mathrm{Xiao}-\mathrm{Chai} \cdot \mathrm{Hu} \cdot \mathrm{Tang} 1 \mu \mathrm{g} / \mathrm{m} l$ group & 8 & $39 \pm 5$ & $43 \pm 10$ & $103 \pm 29^{c}$ & $218 \pm 63^{\mathrm{c}}$ & $5.66 \pm 0.43$ & $5.65 \pm 0.33$ & $7.04 \pm 0.56$ & $7.68 \pm 0.76^{6}$ \\
\hline $\mathrm{PQ}^{2+}+\mathrm{Xiao}$-Chai $\cdot \mathrm{Hu} \cdot \mathrm{Tang} 10 \mu \mathrm{g} / \mathrm{m} l$ group & 8 & $43 \pm 6$ & $65 \pm 19$ & $79 \pm 21^{e}$ & $155 \pm 35^{e}$ & $5.71 \pm 0.35$ & $5.88 \pm 0.44$ & $6.27 \pm 0.69$ & $7.00 \pm 0.68^{\circ}$ \\
\hline $\mathrm{PQ}^{2+}+\mathrm{XiaO}-\mathrm{Chai}-\mathrm{Hu}-\mathrm{T}$ ang $100 \mu \mathrm{g} / \mathrm{m} l$ group & 8 & $38 \pm 4$ & $46 \pm 13$ & $63 \pm 15^{\circ}$ & $133 \pm 34^{e}$ & $5.81 \pm 0.58$ & $5.07 \pm 0.46$ & $6.41 \pm 0.49$ & $7.23 \pm 0.57^{\circ}$ \\
\hline $\mathrm{PQ}^{2+}+$ Xiao-Chai-Hu-Tang $1,000 \mu \mathrm{g} / \mathrm{m} /$ group & 8 & $37 \pm 6$ & $43 \pm 9$ & $62 \pm 13^{\circ}$ & $91 \pm 16^{e}$ & $5.49 \pm 0.20$ & $5.64 \pm 0.20$ & $6.03 \pm 0.19^{d}$ & $6.36 \pm 0.40^{\mathrm{d}}$ \\
\hline
\end{tabular}

Data are expressed as mean \pm S.E.

$: p<0.01$ (vs. control group)

$b: p<0.001$ (vs. control group)

$c: p<0.05$ (vs. $P Q^{2+}$ group)

$: p<0.01$ (vs. $P^{2+}$ group)

$\because p<0.001$ (vs. $\mathrm{PQ}^{2+}$ group) 


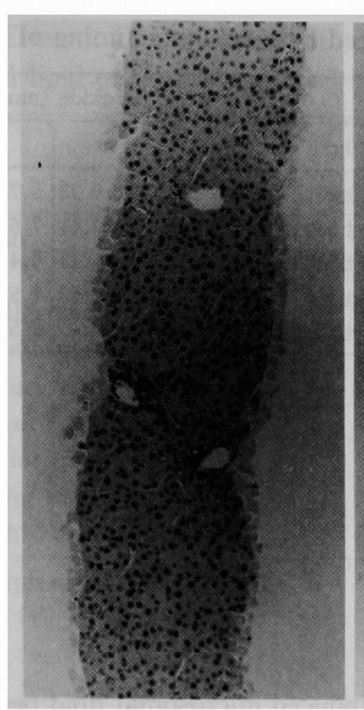

A

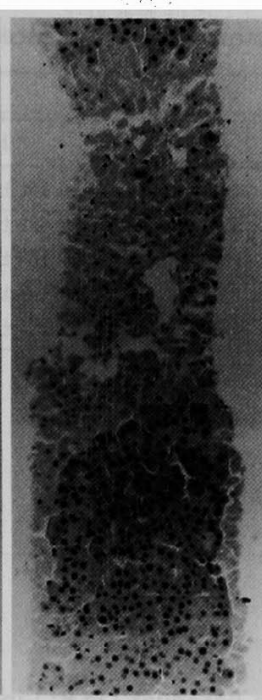

B

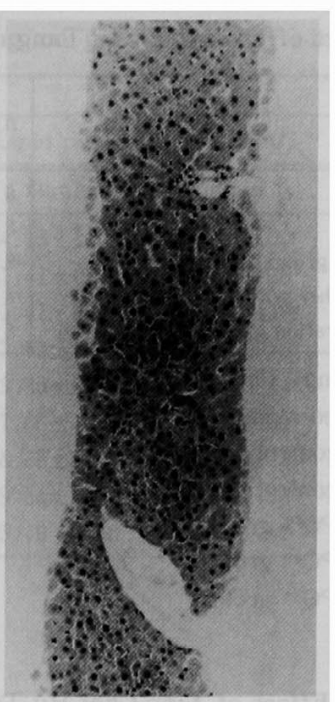

$\mathrm{C}$

Fig. 3 Histology of a liver slice after 8 hours in culture (H \& E stain, $\times 200$ ) $\mathrm{A}:$ Control group, $\mathrm{B}: \mathrm{PQ}^{2+}$ group, $\mathrm{C}: \mathrm{PQ}^{2+}+\mathrm{Xiao}-\mathrm{Chai}-\mathrm{Hu}-\mathrm{T}$ ang $(100 \mu \mathrm{g})$ group Group A shows hardly any, while Group B shows extensive liver cell necrosis. Liver cell necrosis is more suppressed in Group C than in Group B.

Table 2 Effect of Xiao-Chai-Hu-Tang on paraquat $\left(\mathrm{PQ}^{2+}\right)$-induced liver injury -Histology-.

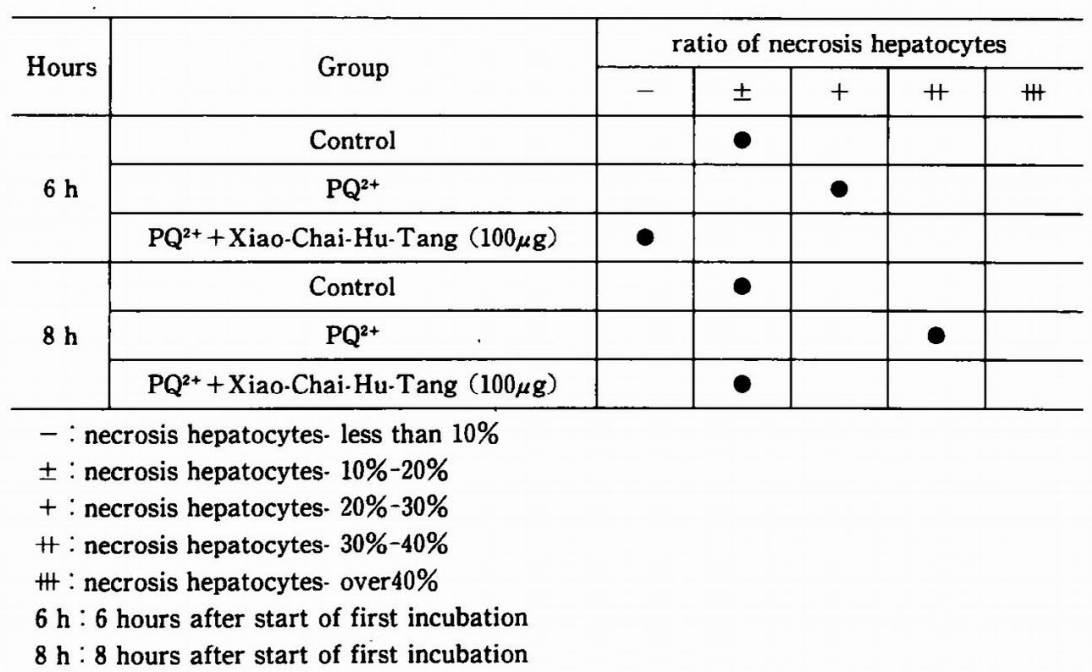

A. 小柴胡湯の microsomal lipid peroxidationの 抑制奻果

対照群, $\mathrm{PQ}^{2+}$ 群の過酸化脂質産生量は各々, 30 分で $1.37 \pm 0.09 \mathrm{nmol} / \mathrm{ml}, 7.86 \pm 1.23 \mathrm{nmol} / \mathrm{m} l, 60$ 分 $4.15 \pm 1.01 \mathrm{nmol} / \mathrm{ml}, 11.41 \pm 0.99 \mathrm{nmol} / \mathrm{ml}, 90$ 分
$5.67 \pm 1.00 \mathrm{nmol} / \mathrm{ml}, 15.75 \pm 1.28 \mathrm{nmol} / \mathrm{ml}, 120$ 分 $8.28 \pm 1.16 \mathrm{nmol} / \mathrm{m} l, 22.24 \pm 1.61 \mathrm{nmol} / \mathrm{m} l$ と対照 群に比ぺ $\mathrm{PQ}^{2+}$ 群は有意に高かった。

$\mathrm{PQ}^{2+}+$ 小柴胡湯 $1 \mu \mathrm{g}, 10 \mu \mathrm{g}, 100 \mu \mathrm{g}$ の 3 群では 30 分 で各々 $4.30 \pm 0.56 \mathrm{nmol} / \mathrm{ml}, 3.97 \pm 0.64 \mathrm{nmol} / \mathrm{ml}$, 
Table 3 Effect of Xiao-Chai-Hu-Tang on paraquat $\left(\mathrm{PQ}^{2+}\right)$-induced liver injury -timing of administration.

\begin{tabular}{l|c|c|c|c|c|c|c|c|c}
\hline & \multirow{4}{|c|}{} & \multicolumn{4}{|c|}{ GOT (IU/L) } & \multicolumn{3}{c}{ Lipid peroxide (nmol/mg protein) } \\
\cline { 3 - 10 } & & $2 \mathrm{hr}$ & $4 \mathrm{hr}$ & $6 \mathrm{hr}$ & $8 \mathrm{hr}$ & $2 \mathrm{hr}$ & $4 \mathrm{hr}$ & $6 \mathrm{hr}$ & $8 \mathrm{hr}$ \\
\hline Control group & 8 & $36 \pm 6$ & $48 \pm 8$ & $75 \pm 7$ & $162 \pm 20$ & $5.65 \pm 0.26$ & $5.72 \pm 0.23$ & $5.75 \pm 0.26$ & $6.60 \pm 0.20$ \\
$\mathrm{PQ}^{2+}$ group & 8 & $64 \pm 12$ & $57 \pm 13$ & $247 \pm 34^{\mathrm{b}}$ & $499 \pm 56^{\mathrm{b}}$ & $5.78 \pm 0.22$ & $6.58 \pm 0.41$ & $7.63 \pm 0.28^{\mathrm{a}}$ & $12.93 \pm 0.98^{\mathrm{*}}$ \\
Prior administration group $_{\text {Administration together with } \mathrm{PQ}^{2+} \text { group }}$ & 8 & $38 \pm 4$ & $46 \pm 13$ & $63 \pm 15^{\mathrm{e}}$ & $133 \pm 34^{\mathrm{e}}$ & $5.81 \pm 0.58$ & $5.07 \pm 0.46$ & $6.41 \pm 0.49$ & $7.23 \pm 0.57^{\mathrm{a}}$ \\
Subsequent administration group & 8 & $54 \pm 19$ & $65 \pm 7$ & $56 \pm 6^{\mathrm{e}}$ & $135 \pm 34^{\mathrm{e}}$ & $5.10 \pm 0.20$ & $5.58 \pm 0.52$ & $7.57 \pm 0.80$ & $7.72 \pm 0.30^{\mathrm{c}}$ \\
\hline & 8 & $37 \pm 3$ & $41 \pm 5$ & $113 \pm 31^{\mathrm{c}}$ & $214 \pm 46^{\mathrm{c}}$ & $5.93 \pm 0.64$ & $6.42 \pm 0.41$ & $8.52 \pm 0.41$ & $8.77 \pm 0.65^{\mathrm{c}}$ \\
\hline
\end{tabular}

Xiao-Chai-Hu-Tang: $100 \mu \mathrm{g} / \mathrm{ml}$

Data are expressed as mean \pm S.E.

a $p<0.01$ (vs. control group)

$\therefore$ : $<0.001$ (vs. control group)

c : $p<0.05$ (vs. $\mathrm{PQ}^{2+}$ group)

d $: p<0.01$ (vs. $\mathrm{PQ}^{2+}$ group)

$: p<0.001$ (vs. $\mathrm{PQ}^{2+}$ group)

Table 4 Effect of Xiao-Chai-Hu-Tang on paraquat $\left(\mathrm{PQ}^{2+}\right)$-induced microsomal lipid peroxidation.

\begin{tabular}{|c|c|c|c|c|c|}
\hline & \multirow{2}{*}{$\mathbf{n}$} & \multicolumn{4}{|c|}{ Lipid peroxide $(\mathrm{nmol} / \mathrm{m} l)$} \\
\hline & & $30 \mathrm{~min}$ & $60 \mathrm{~min}$ & $90 \mathrm{~min}$ & $120 \mathrm{~min}$ \\
\hline Control group & 8 & $1.37 \pm 0.09$ & $4.15 \pm 1.01$ & $5.67 \pm 1.00$ & $8.28 \pm 1.16$ \\
\hline $\mathrm{PQ}^{2+}$ group & 8 & $7.86 \pm 1.23^{\mathrm{a}}$ & $11.41 \pm 0.99^{\mathrm{a}}$ & $15.75 \pm 1.28^{\circ}$ & $22.24 \pm 1.61^{\mathrm{b}}$ \\
\hline $\mathrm{PQ}^{2+}+$ Xiao-Chai-Hu-Tang $1 \mu \mathrm{g} / \mathrm{m} l$ group & 8 & $4.30 \pm 0.56$ & $6.27 \pm 0.63^{\mathrm{d}}$ & $8.30 \pm 0.55^{\circ}$ & $14.82 \pm 1.59^{c}$ \\
\hline $\mathrm{PQ}^{2+}+\mathrm{X}$ iao-Chai-Hu-Tang $10 \mu \mathrm{g} / \mathrm{m} l$ group & 8 & $3.97 \pm 0.64$ & $5.90 \pm 1.00^{c}$ & $8.34 \pm 0.88^{a}$ & $15.80 \pm 1.30^{\mathrm{c}}$ \\
\hline $\mathrm{PQ}^{2+}+\mathrm{Xiao}-\mathrm{Chai} \cdot \mathrm{Hu} \cdot \mathrm{Tang} 100 \mu \mathrm{g} / \mathrm{m} l$ group & 8 & $3.84 \pm 0.98$ & $4.94 \pm 1.12^{\circ}$ & $6.97 \pm 0.64^{d}$ & $10.89 \pm 0.73^{\circ}$ \\
\hline $\mathrm{PQ}^{2+}+\mathrm{Xiao}-\mathrm{Chai}-\mathrm{Hu}-\mathrm{Tang} 1,000 \mu \mathrm{g} / \mathrm{m} l$ group & 8 & $2.44 \pm 0.43^{d}$ & $4.01 \pm 0.51^{\mathrm{d}}$ & $5.87 \pm 0.46^{e}$ & $5.50 \pm 0.30^{e}$ \\
\hline
\end{tabular}

Data : mean \pm S.E.

$\because \mathbf{p}<0.01$ (vs. control group)

$b: p<0.001$ (vs. control group)

$c: p<0.05$ (vs. $P^{2+}$ group)

$d: p<0.01$ (vs. $P^{2+}$ group)

$e: p<0.001$ (vs. $P Q^{2+}$ group)

$3.84 \pm 0.98 \mathrm{nmol} / \mathrm{m} l$ と $\mathrm{PQ}^{2+}$ 群に比べ有意差はみら れなかったが， $\mathrm{PQ}^{2+}$ 十小柴胡湯 $1000 \mu \mathrm{g}$ 群では2.44士 0.43 と有意 $(\mathrm{p}<0.001)$ に過酸化脂質産生の抑制が2 られた。 反応開始60分以後では $\mathrm{PQ}^{2+}$ 群に比べ $\mathrm{PQ}^{2+}+$ 小柴胡湯の 4 群とも有意に過酸化脂質産生は抑制され た (Table 4).

B. 小柴胡湯構成生薬の microsomal lipid peroxidation の抑制効果

小柴胡湯構成生薬の中で黄芩, 甘草, 柴胡の過酸化 脂質産生量は各々, 30 分で $1.16 \pm 0.21 \mathrm{nmol} / \mathrm{ml}$, $2.04 \pm 0.33 \mathrm{nmol} / \mathrm{m} l, 1.36 \pm 0.15 \mathrm{nmol} / \mathrm{ml}, 60$ 分で $1.41 \pm 0.17 \mathrm{nmol} / \mathrm{ml}, 3.63 \pm 0.88 \mathrm{nmol} / \mathrm{m} l, 3.30 \pm$ $0.37 \mathrm{nmol} / \mathrm{ml}, 90$ 分で $1.84 \pm 0.10 \mathrm{nmol} / \mathrm{ml}, 4.55 \pm$ $0.76 \mathrm{nmol} / \mathrm{ml}, 4.53 \pm 0.44 \mathrm{nmol} / \mathrm{ml}, 120$ 分で $2.14 \pm$ $0.13 \mathrm{nmol} / \mathrm{m} l, \quad 5.95 \pm 0.57 \mathrm{nmol} / \mathrm{m} l, 8.39 \pm 0.71$ $\mathrm{nmol} / \mathrm{m} l$ と，ともに $\mathrm{PQ}^{2+}$ 群に比べ有意に過酸化脂質 産生を㸡制した（Table 5)。

\section{考察}

今回用いた実験法は、ラット肝をスライスにしたも のである，肝スライスは，肝小葉構造を保っているの で組織像について検討が可能であること, 手技が簡便 であることの 2 点で初代培盖遊離肝細胞に比へ，優れ ている．欠点として酸素や栄盖の拡散が不十分なため 長時間培着するのが困難なこと，均一なスライスを多 量に得るのが困難なことが挙げられる(5). しかし本実 験にあたり， rotary slicer を用いることにより均一で 挫減の少ない肝スライスを多量に作成できた。むたこ の肝スライスはMEMで培養した対照群で, preincubation 開始から2nd incubation 終了まで 9 時間30 分にわたって組織学的, 生化学的に恒常性を保持しえ 
Table 5 Effect of galenicals contained in Xiao-Chai-Hu-Tang on paraquat $\left(\mathrm{PQ}^{2+}\right)$-induced microsomal lipid peroxidation.

\begin{tabular}{l|c|c|c|c|c}
\hline & \multirow{2}{*}{$\mathrm{n}$} & \multicolumn{4}{|c}{ Lipid peroxide $(\mathrm{nmol} / \mathrm{m} l)$} \\
\cline { 3 - 6 } & & $30 \mathrm{~min}$ & $60 \mathrm{~min}$ & $90 \mathrm{~min}$ & $120 \mathrm{~min}$ \\
\hline Control group & 8 & $1.37 \pm 0.09$ & $4.15 \pm 1.01$ & $5.67 \pm 1.00$ & $8.28 \pm 1.16$ \\
$\mathrm{PQ}^{2+}$ group & 8 & $7.86 \pm 1.23^{\mathrm{a}}$ & $11.41 \pm 0.99^{\mathrm{a}}$ & $15.75 \pm 1.28^{\mathrm{a}}$ & $22.24 \pm 1.61^{\mathrm{b}}$ \\
$\mathrm{PQ}^{2+}+$ Scutellariae Radix group & 8 & $1.16 \pm 0.21^{\mathrm{d}}$ & $1.41 \pm 0.17^{\mathrm{e}}$ & $1.84 \pm 0.10^{\mathrm{e}}$ & $2.14 \pm 0.13^{\mathrm{e}}$ \\
$\mathrm{PQ}^{2+}+$ Glycyrrhizae Radix group & 8 & $2.04 \pm 0.33^{\mathrm{c}}$ & $3.63 \pm 0.88^{\mathrm{d}}$ & $4.55 \pm 0.76^{\mathrm{e}}$ & $5.95 \pm 0.57^{\mathrm{e}}$ \\
$\mathrm{PQ}^{2+}+$ Bupleuri Radix group & 8 & $1.36 \pm 0.15^{\mathrm{d}}$ & $3.30 \pm 0.37^{\mathrm{e}}$ & $4.53 \pm 0.44^{\mathrm{e}}$ & $8.39 \pm 0.71^{\mathrm{e}}$ \\
$\mathrm{PQ}^{2+}+$ Zingiberis Rhizoma group & 8 & $3.02 \pm 0.38$ & $7.66 \pm 1.00$ & $8.99 \pm 0.52$ & $14.41 \pm 1.64^{\mathrm{c}}$ \\
$\mathrm{PQ}^{2+}+$ Pinelliae Tuber group & 8 & $3.04 \pm 0.31$ & $8.38 \pm 0.86$ & $13.63 \pm 1.45$ & $21.72 \pm 1.09$ \\
$\mathrm{PQ}^{2+}+$ Ginseng Radix group & 8 & $3.21 \pm 0.40$ & $9.34 \pm 0.57$ & $14.27 \pm 1.58$ & $23.12 \pm 1.44$ \\
$\mathrm{PQ}^{2+}+$ Zizyphi Fructus group & 8 & $3.75 \pm 0.22$ & $5.46 \pm 0.68$ & $15.36 \pm 1.52$ & $19.96 \pm 1.19$ \\
\hline
\end{tabular}

Data are expressed as mean \pm S.E.

$: p<0.01$ (vs. control group)

$: p<0.001$ (vs. control group)

$c: p<0.05$ (vs. $\mathrm{PQ}^{2+}$ group)

$d: p<0.01$ (vs. $P^{2+}$ group)

$e: p<0.001$ (vs. $P^{2+}$ group)

た.これは対照群で GOT の逸脱, 肝スライス内 LPO の上昇, 組織学的変化が少ないことから確認した。し たがって，肝スライス培養法を用いた本実験は十分検 討に耐えるすのであるといえる。

LPOは八木別法で測定した，従来のTBA法は malondialdehyde(MDA)を測定するすのであり， $\mathrm{pH}$ や共存物質などにより数值が大きく变動するといわれ ている ${ }^{16)}$.八木別法はLPOの-OOH の部位とメチレン ブルー誘導体がへモクロビンを触蝶として反応し， メ チレンブルーを生成することを利用したもので，直接 LPO を定量できる利点があり，現段階では最も信頼で きるLPO の测定法である ${ }^{11}$.

$\mathrm{PQ}^{2+}$ はミクロソームの菜物代謝䤃素で $\mathrm{O}_{2}$-を生し， この $\mathrm{O}_{2}$-により膜脂質の不飽和脂肪酸から脂質ラシカ ルが生成される，脂質ラジカルがさらに酸素と反応し 脂筫ベルオキシラジカルになる．脂質ベルオキシラシ カルが他の不飽和脂肪酸から水素を孪い過酸化脂質に なるとともに新たに脂質ラジカルを生成する。このよ 5な連鎖成長反応に上り過酸化脂質が生成されてく る゙.我々は肝スライスを用いた夷馀で， $\mathrm{PQ}^{2+}$ 肝障害は superoxide dismutase (SOD)の阻害用である diethyldithiocarbamate で増強し, liposomal SOD で 軽減することから， $\mathrm{PQ}^{2+}$ 肝障害は活性酸素 $\left(\mathrm{O}_{2}^{-}\right)$Kよ ることを明らかにしだ,7.

今回肝スライスを用いた串験では小柴胡湯は $\mathrm{PQ}^{2+}$ による培羪上清中へのGOT の逸脱，肝スライス中過
酸化脂筫の増加，および肝細胞壊死を抑制することを 示しえた。したがって，小柴胡湯には $\mathrm{PQ}^{2+}$ 肝障害抑制 作用があると思われた。 そして小柴胡湯濃度 $1000 \mu \mathrm{g}$ が 最も良くGOT の逸脱を抑制し，次いで100 $\mu \mathrm{g}, 10 \mu \mathrm{g}$, $1 \mu \mathrm{g}$ の順であったことから小柴胡湯は $\mathrm{PQ}^{2+}$ 肝障害を 湦度依存的に抑制するものと思われた。

小柴胡湯か $\mathrm{PQ}^{2+}$ 肝障害を抑制する機序としては, (1) $\mathrm{PQ}^{2+}$ の肝細胞内への取り込み抑制, (2) $\mathrm{PQ}^{2+}$ によっ て産生される活性酸素の消去作用，(3)産生された過酸 化脂質によってひき起こされる肝障害の抑制，などが 考えられる.この中で(3)については小柴胡湯は過酸化 脂質の産生そのるのを抑制しているので，小柴胡湯の $\mathrm{PQ}^{2+}$ 肝障害抑制の機序としては考えにくいるのと思 われる. (1)の， $\mathrm{PQ}^{2+}$ の肝細胞内への取り込みを小柴胡 湯が抑制するかについては直接には検討していない， しかし， $\mathrm{PQ}^{2+}$ 一定時間訮スライスと培養し， $\mathrm{PQ}^{2+}$ 肝細胞に取り込まれた後で小柴胡湯を投与してす訮障 害を抑制しえたことから，小柴胡湯の $\mathrm{PQ}^{2+}$ 肝障害抑 制作用は $\mathrm{PQ}^{2+}$ の肝細胞内への取り込み抑制では説明 できないものと思われる。

小柴胡湯の $\mathrm{O}_{2}$-消去作用を直接証明してはいない が，小柴胡湯には肝ミクロンームでの lipid peroxidation 抑制作用があることから，小柴胡湯の $\mathrm{PQ}^{2+}$ 肝障 害抑制は脂犋過酸化反心抑制作用によるものと考えら れた.これは，今回の肝スライスを用いた実験で，小 柴胡湯の投与時期でみると $\mathrm{PQ}^{2+}$ 肝障害の抑制は前投 
与で最も良く，次いで同時投与であることから，小柴 胡湯の投与時期が早い注ど効果のあること，また小柴 胡湯投与に上り過酸化脂質産生量が抑えられることな どから裏づけられる。

小柴胡湯には多量のフラボン類が含まれている。 ラボン類には $\mathrm{O}_{2}$-消去作用がみとめられている ${ }^{17}$.す なわちフラボン類の水酸基が $\mathrm{O}_{2}$-と反応し，最終的に はアルコール類となり，分解される。フフラボン類の一 種のケンフェロールは $\mathrm{O}_{2}$-と反応して 3 位の水酸基の 酸化によりケンフェロールラジカルが形成される。 こ れはさらに酸化されてケトヒドロペルオキシドになっ た後，還元されて4・ヒドロキシフェニルダリオキシル 酸と 2,4,6-トリヒドロキシ安息香酸となり， $\mathrm{O}_{2}$ 一は消去 される ${ }^{18}$. 肝スライス培養法では $\mathrm{PQ}^{2+}$ 肝障害は $\mathrm{O}_{2}{ }^{-}$に

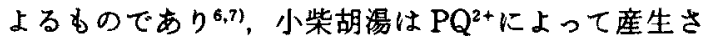
れる $\mathrm{O}_{2}$-を消去して訮障害を抑制する可能性が高いと 思われる。

さらに各生真について，小柴胡湯の活性酸素消去能 がれらの生省の何によるむのなのかをみるために $\mathrm{PQ}^{2+}$ による訮ミクロソーム脂質過酸化反応で各生薬 の抑制を検討した，その結果，黄芩，甘草，柴胡に抗 酸化作用のあることが確認された。したがって，小柴 胡湯構成成分の中で活珄酸素消去作用の中心をなする の灶黄芩, 甘草, 柴胡と考齐られる。

\section{文献}

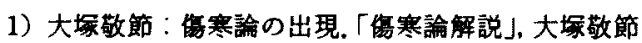
著. 創元社，大阪，1966，pl7-28

2）岡博，藤原研司，与芝 真：漠方治療の実際 一慢性肝炎。内科 $56: 833-836,1988$

3）溝口靖紘：小柴胡湯の抗炎症作用。「慢性肝炎にお

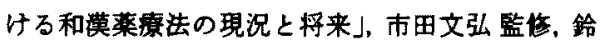
木 宏, 藤哖 洌編集, 国際医書出版。東京, 1988. p74-78

4）小坂二度見，山田蛼夫, 阿部晋也：ダラモキンン中 毒. ICU と CCU 6:637-646, 1982

5) Bus JS, Aust SD, Gibson JE : Superoxide- and singlet oxygen-catalyzed lipid peroxidation as a possible mechanism for paraquat (methyl viologen) toxicity. Biochem Biophys Res Commun 58 : 749-755, 1974

6）富樫 整，若林博人，新沢陽英：Paraquat 盰障害 における $\mathrm{O}_{2}$-の関与の検討。肝眼 29(Suppl): 122,
1988

7) 中村東一郎, 冨堅 整, 若林博人, 他：ハラコート

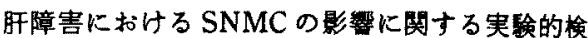
討. 日消誌 $85: 513,1988$

8) Kaneda M, Higashitani $Y$, Ohtani $R$, et al : A rotary slicer for brain research. Yamagata Med J $4: 81-85,1986$

9) Yamane I, Matsuya $Y$, Jimbo $K$ : An autoclavable powdered culture medium for mam. malian cells. Proc Soc Exp Biol Med 127 : 335 $-336,1968$

10) International Federation of Clinical Chemistry, Committee on Standards, Part 2. IFCC Method for Asparate Aminotransferase. Amsterdam, Elsevier Scientific Publishing Company, 1975

11) Ohishi N, Ohkawa $H$, Miike A, et al: A new assay method for lipid peroxides using a methylene blue derivative. Biochem Int $10: 205-211$, 1985

12）今井宣子，山西八朗，大東律子, 他：ビロカロール レッドモリブデン錯体発色法を用いた尿缽量タン ハク 測定用キットの検討. 臨床検査機器・試薬 8 ： $899-902,1985$

13) Mimnaugh EG, Gram TE, Trush MA : Stimulation of mouse heart and liver microsomal lipid peroxidation by anthracycline anticancer drugs : Characterization and effect of reactive oxygen scavengers. J Pharmacol Exptl Therapy $226: 806-816,1983$

14）雨谷 夈, 岩間裕子, 清水孝次, 他：小柴胡湯の抗 炎店作用。和嫨医菜誌 $1: 134-135,1984$

15) Smith PF, Krack G, Mckee RL, et al : Maintenance of adult rat liver slices in dynamic organ culture. In Vitro Cell Dev Biol 22: 706-712, 1986

16）内山 充：過酸化脂質の测定.「過酸化脂質と生 体」, 内山 充, 松尾光芳, 嶕峨井勝編, 学会出版 センター、東京，1985，p6一9

17) Robak J, Gryglewski RJ : Fravonoids are scavengers of superoxide anions. Biochem Pharmacol. $37: 837-841,1988$

18）高演有明夫：活性酸素の消去一フラボノイド，蛋 核酵 $33: 2994-2999,1988$ 


\title{
Effect of Xiao-Chai-Hu-Tang on paraquat-induced liver injury
}

\author{
Toichiro Nakamura,Tsuneo Takahashi, Haruhide Shinzawa,
} Hitoshi TogashI and Makoto IsHIKAWA*

By means of liver slice culture, the suppressive effect of Xiao-Chai-Hu-Tang on hepatic injury due to paraquat $\left(\mathrm{PQ}^{2+}, 1,1^{\prime}\right.$-dimethyl-4-4'-bipyridinium ion, methyl viologen) was examined in terms of released GOT, LPO in liver slices and histologic features of he liver. Then, the effects of Xiao-Chai-HuTang on hepatic microsomal lipid peroxidation mediated by $\mathrm{PQ}^{2+}$ were studied. The results were as follows. 1) Upon liver slice culture, Xiao-Chai-Hu-Tang showed dose-dependent suppression of $\mathrm{PQ}^{2+}$. induced hepatic injury. Although Xiao-Chai-Hu-Tang suppressed hepatic injury regardless of whether it was added to the medium before (Prior administration group), at the same time as (Administration together with $\mathrm{PQ}^{2+}$ group) or after (Subsequent administration group) the addition of $\mathrm{PQ}^{2+}$, the suppression was most marked in the case of prior administration, followed by administration together with $\mathrm{PQ}^{2+}$. 2) Xiao-Chai-Hu-Tang suppressed hepatic microsomal lipid peroxidation mediated by $\mathrm{PQ}^{2^{+}}$, liver microsomes and the NADPH generating system. Among galenicals constituting Xiao-Chai-HuTang, Scutellariae Radix, Glycyrrhizae Radix and Bupleuri Radix were found to suppress hepatic microsomal lipid peroxidation. These results suggest that Xiao-Chai-Hu-Tang suppresses active oxygen-induced hepatic injury.

\footnotetext{
* The Second Department of Internal Medicine, Yamagata University School of Medicine (Yamagata)
} 